\title{
Qualidade, indicadores e sustentabilidade
}

\section{Quality, indicators, and sustainability}

Podemos considerar que o movimento da qualidade laboratorial se iniciou no Brasil na década de 1970 com o lançamento, pela Sociedade Brasileira de Patologia Clínica/Medicina Laboratorial (SBPC/ML), em parceria com a Control-Lab, do Programa de Excelência para Laboratórios Médicos (PELM). Naquele momento, os profissionais de laboratório buscavam ferramentas para assegurar a precisão e a exatidão dos resultados analíticos, de modo que as informações contidas nos laudos dos exames pudessem ser utilizadas para a correta assistência à saúde.

Um novo marco estabeleceu-se ao final da década de 1990, com o lançamento do Programa de Acreditação de Laboratórios Clínicos (PALC) ${ }^{(1)}$ da própria SBPC/ML. O PALC já nasceu com requisitos voltados a todas as fases do processo laboratorial, implicando cuidados com infraestrutura e relacionamentos da equipe com o ambiente extralaboratorial.

Em uma evolução natural, em 2005, foi lançado o 1ำ Programa de Indicadores Laboratoriais ${ }^{(2)}$, também resultante de parceria entre SBPC/ML e Control-Lab, que visou oferecer à comunidade laboratorial uma ferramenta de benchmarking, contribuindo, assim, para a melhoria contínua dos serviços oferecidos pelos laboratórios brasileiros.

Novos desafios estão sendo impostos às organizações de todos os tipos, no sentido de atingirem e demonstrarem desempenhos ambientais, econômicos e sociais adequados, controlando os impactos de suas relações, processos, produtos e serviços na sociedade, de forma consistente com sua política e seus objetivos de responsabilidade social; em outras palavras, o foco passou a ser o cuidado na preservação dos ambientes externo e social. Muitos laboratórios já avançaram na implantação dessas práticas. Depois das normas ISO 14001 e ISO 16001, da Organização Internacional para Padronização (ISO), referentes à gestão ambiental e à responsabilidade social, respectivamente, já adotadas por vários laboratórios clínicos no final de 2010, foi publicada a norma internacional ISO 26000 - Diretrizes sobre Responsabilidade Social. No Brasil, a norma da Associação Brasileira de Normas Técnicas (ABNT) NBR ISO $26000^{(3)}$ foi lançada em dezembro de 2010. Segundo essa norma, a responsabilidade social se expressa pelo propósito das organizações em incorporar considerações socioambientais em seus processos decisórios e responsabilizar-se pelos impactos de suas decisões e atividades na sociedade e no meio ambiente. Isso implica um comportamento ético e transparente que contribua para o desenvolvimento sustentável, que esteja em conformidade com as leis aplicáveis e seja consistente com as normas internacionais de comportamento. Diferentemente da maioria das normas, a ISO 26000 foi concebida como uma norma "guarda-chuva", que englobou conceitos de outras normas para ser uma diretriz normativa não certificável, ou seja, uma norma-guia, uma norma de conduta. 
Todo o esforço empreendido pela SBPC/ML ao longo desses anos, solidificado por meio de seus programas, se vê recompensado e refletido nesta edição do Jornal Brasileiro de Patologia e Medicina Laboratorial (JBPML), pela publicação de artigos de autores brasileiros, oriundos tanto do setor público como do privado, que nos trazem relatos sobre qualidade, processos, indicadores e sustentabilidade em laboratórios clínicos. Dessa forma, a SBPC/ML acredita que os laboratórios clínicos brasileiros continuarão evoluindo, posicionando-se em níveis similares aos laboratórios de países do Primeiro Mundo e prestando bons serviços à sociedade brasileira.

\section{Referências}

1. Norma PALC 2010. Disponível em: <www.sbpc.org.br>.

2. Programa de Indicadores Laboratoriais SBPC/Controlab. Disponível em: <www.controllab.com.br>.

3. NBR ISO 26000 - Diretrizes sobre Responsabilidade Social. 